\title{
Perbandingan Model Pembelajaran TSTS, TAI dan TPS Terhadap Hasil Belajar Matematika Siswa Smk
}

\author{
Sumargiyani, Mufika Syahfitri, Fatimatus Solihah, Maulida Asih Khairani \\ Program Studi Pendidikan Matematika FKIP UAD \\ *Coresponding author: sumargiyani04@yahoo.com
}

\section{AR T I C LE INF O}

Article history:

Received: 24 Mei 2019

Accepted: 12 September 2019

\section{Keywords:}

TSTS, TAI, TPS,

Matematika

\begin{abstract}
ABSTRAK
Penelitian ini bertujuan untuk mengetahui perbedaan yang bermakna rerata hasil belajar matematika pada kelas XI Akuntansi SMK Muhammadiyah 1 Turi Tahun Pelajaran 2018/2019 yang pembelajarannya menggunakan model pembelajaran TSTS, TAI dan TPS. Populasi dari penelitian ini semua siswa kelas XI akuntansi SMK Muhammadiyah 1 Turi kabupaten Sleman. Sampel terdiri dari tiga kelas, diperoleh kelas A untuk model pembelajaran TSTS, kelas $\mathrm{B}$ untuk model pembelajaran TAI dan kelas $\mathrm{C}$ untuk model pembelajaran TPS. Instrumen pengumpulan data menggunakan tes. Uji prasyarat analisis : uji normalitas dan uji homogenitas. Uji hipotesis menggunakan uji ANOVA satu jalur. Hasil penelitian diperoleh Fhitung $=0,069<$ Ftabel 3,142 . Hal ini menunjukkan tidak ada perbedaan yang bermakna rerata hasil belajar matematika pada kelas XI Akuntansi SMK Muhammadiyah 1 Turi Tahun Pelajaran 2018/2019 yang pembelajarannya menggunakan model pembelajaran TPS,TAI maupun TSTS
\end{abstract}

\section{PENDAHULUAN}

Pendidikan memegang peranan penting dalam menghadapi tantangan zaman serta perkembangan ilmu pengetahuan dan teknologi. Berbagai upaya dilakukan pemerintah untuk mencerdaskan anak bangsa salah satunya dengan meningkatkan kualitas proses belajar mengajar di sekolah. Selain itu pemerintah juga meningkatkan perbaikan mutu pendidikan dengan pembaharuan kurikulum untuk meningkatkan potensi siswa dalam memaksimalkan proses belajar mengajar (Ali, \& Arif, 2019). Dalam proses belajar mengajar permasalahan tidak hanya berasal dari guru saja tetapi dari siswa juga (Darmawan, et al., 2019).

Permasalahan yang berasal dari guru diantaranya dalam menyajikan materi pelajaran matematika kebanyakan dengan menggunakan model pembelajaran yang bersifat monoton dan kurang bervariasi sehingga kurang menarik dan membosankan bagi siswa. Hal ini yang menyebabkan siswa cenderung pasif dalam mengikuti pelajaran. 
Kondisi seperti ini juga dialami pada siswa kelas XI jurusan akuntansi SMK Muhammadiyah 1 Turi. Slameto dalam Sumargiyani (2015) menyatakan guru harus mempergunakan banyak metode pada waktu mengajar. Variasi metode pengajaran mengakibatkan penyajian bahan pelajaran lebih menarik perhatian siswa, mudah diterima siswa, dan kelas menjadi lebih hidup. Metode penyajian yang sama akan membosankan siswa. Sesuai dengan tuntutan profesional guru, maka seorang guru harus memiliki kemampuan dalam mengembangkan model mengajarnya sedemikian rupa sehingga mampu mengeksplorasi keaktifan belajar siswa dalam proses belajar mengajar. Permasalahan yang terjadi pada siswa SMK Muhammadiyah 1 Turi kelas XI akutansi terletak pada kecenderungan siswa yang pasif dalam pembelajaran. Selain itu, siswa kurang termotivasi dalam belajar, sehingga mengakibatkan hasil belajar matematika rendah.

Oleh karena itu seorang guru harus mampu melakukan inovasi pembelajaran (Isfaeni, Corebima, Suwono, \& Rohman, 2018). Dengan adanya berbagai macam model pembelajaran diharapkan guru dapat memilih dan menerapkannya dalam proses pemblajaran, sehingga dapat meningkatkan aktivitas siswa dalam belajar yang akan berdampak positif terhadap hasil belajar siswa. Salah satu model yang dapat diterapkan adalah dengan menerapkan model pembelajaran kooperatif. Pembelajaran kooperatif adalah pembelajaran secara berkelompok dan tidak menekankan pada situasi pengalaman siswa (Ristanto, Zubaidah, Amin, \& Rohman, 2018a, 2018b). Pada pembelajaran kooperatif, siswa belajar dalam kelompok-kelompok kecil yang terdiri dari 4-6 siswa yang sederajat tetapi heterogen, kemampuan, jenis kelamin, suku atau ras, dan satu sama lain saling membantu. Tujuan dibentuknya kelompok tersebut adalah untuk memberikan kesempatan kepada semua siswa untuk dapat terlibat secara aktif dalam proses berpikir dan kegiatan belajar. Selama bekerja dalam kelompok, tugas anggota kelompok adalah mencapai ketuntasan materi yang disajikan guru, dan saling membantu teman sekelompoknya untuk mencapai ketuntasan belajar Trianto dalam Sipayung (2017). Model - model pembelajaran yang penulis terapkan dalam penelitian dengan adalah model pembelajaran kooperatif tipe TSTS, TAI, dan TPS. Berdasarkan hasil Penelitian dengan model Teams Assisted Individualization (TAI) rata-rata hasil belajar matematika lebih tinggi dari pada menggunakan metode ekspositori, karena peserta didik lebih aktif dalam mengerjakan soal yang diberikan (Achdiyat, 2016), menjadikan siswa lebih termotivasi (Krestian, 2017), dapat meningkatkan motivasi dan hasil belajar matematika (Meizha 2014). Hasil penelitian dengan menerapkan model Two Stay Two Stray (TSTS) rata-rata hasil belajar matematika kelas eksperimen yang menggunakan model TSTS lebih baik dari pada rata-rata hasil belajar matematika kelas kontrol yang menggunakan pembelajaran langsung (Habibi, 2014), menjadikan siswa lebih aktif (Herawati, 2015), mampu meningkatkan kemampuan pemecahan masalah matematika (Ariyanto, 2018). Untuk hasil penelitian dengan model pembelajaran Think Pair Share (TPS) menjadikan aktivitas belajar meningkat (Kesumawardani dkk, 2016), memberi pengaruh terhadap hasil belajar matematika (Nurmalaningrum, 2018). Model pembelajaran Think Pair Share (TPS) merupakan model pembelajaran kooperatif yang menempatkan siswa secara berpasangan untuk menyelesaikan tugas-tugas akademik melalui tiga tahap, yaitu: Think (berfikir), Pair (berpasangan), dan Share (berbagi). Salah satu keutamaan model pembelajaran kooperatif tipe TPS yaitu dapat menumbuhkan keterlibatan dan keikutsertaan siswa dengan memberikan kesempatan terbuka pada siswa untuk berbicara dan mengutarakan gagasannya sendiri dan memotivasi siswa untuk terlibat percakapan dalam kelas. (Marlina,dkk, 2014). Model pembelajaran Team Assisted Individualization (TAI) merupakan salah satu bentuk pembelajaran yang menempatkan siswa dalam kelompok-kelompok kecil yang heterogen, antara lain dari segi nilai akademik dan jenis kelamin. Pengelompokan ini masing-masing kelompok beranggotakan 4-5 orang siswa Salah satu dari anggota kelompok sebagai seorang ketua yang bertanggung jawab atas 
keberhasilan kelompoknya. Kelompok-kelompok kecil yang beranggotakan 4-5 orang secara heterogen yang terlebih dahulu belajar secara individual yang selanjutnya berdiskusi dalam kelompok yang telah ditentukan (Nurzakiaty, 2015). Lie dalam (Rohmana,dkk 2016). Model Two Stay Two Stray (TSTS) merupakan salah satu model pembelajaran kooperatif untuk menghadapi kemampuan heterogen siswa yang dilakukan dengan membentuk kelompok yang bersifat heterogen kemudian saling bertukar informasi dengan kelompok lain.

Setiap pembelajaran yang dilakukan sebaiknya dievaluasi untuk mengetahui keefektifan pembelajaran tersebut. Menurut Miarso (dalam Rohmawati, 2015: 16) efektivitas pembelajaran merupakan salah satu standar mutu pendidikan dan sering kali diukur dengan tercapainya tujuan, atau dapat juga diartikan sebagai ketepatan dalam mengelola suatu situasi, (doing the right things). Tujuan dari proses kegiatan belajar mengajar diantaranya tercapainya hasil belajar siswa yang optimal. Menurut Agus Suprijono (2012:5), hasil belajar adalah pola-pola perbuatan, nilai-nilai, pengertianpengertian, sikap-sikap, apresiasi dan keterampilan. Sementara menurut Lindgren dalam Agus Suprijono (2012: 7), menjelaskan bahwa hasil pembelajaran meliputi kecakapan, informasi, pengertian, dan sikap. Hasil belajar untuk pelajaran matematika biasanya diwujudkan dalam bentuk nilai setelah dilakukan tes kognitif.

Berdasarkan uraian tersebut, maka penulis tertarik untuk menerapkan model pembelajaran kooperatif tipe TSTS, TAI, dan TPS di kelas XI jurusan akuntansi SMK Muhammadiyah 1 Turi kabupaten Sleman tahun pelajaran 2019/2020 untuk mengetahui model pembelajaran yang efektif untuk mengajarkan mata pelajaran matematika.

\section{METODE PENELITIAN}

Penelitian dilakukan di SMK Muhammadiyah Turi pada semester genap Tahun Pelajaran 2018/2019. Penelitian ini menggunakan metode eksperimen dengan desain quasi experimental. Populasi penelitian ini adalah seluruh siswa kelas XI jurusan akutansi SMK Muhammadiyah 1 Turi semester gasal tahun pelajaran 2018/2019. Jumlah anggota populasi sebanyak 68 orang. Pada masing - masing kelas diberikan perlakuan yang berbeda, untuk kelas A dengan diterapkan model pembelajaran TSTS, kelas B dengan menerapkan model pembeajaran TAI dan kelas C dengan menerapkan model pembelajaran TPS. Populasi dalam penelitian ini adalah seluruh siswa kelas XI SMK Muhammadiyah 1 Turi yang terdiri dari 3 kelas pada jurusan akuntansi tahun pelajaran 2018/2019. Sampel penelitian ada sebanyak tiga kelas yaitu kelas A sebagai kelas eksperimen I, kelas B sebagai eksperimen II dan kelas C sebagai kelas eksperimen III. Teknik pengumpulan data berupa teknik tes untuk mengambil data kemampuan awal dan post tes untuk hasil belajar setelah diberikan perlakuan.

Sebelum melakukan pengujian hipotesis dilakukan uji prasyarat analisis yaitu uji normalitas dan uji homogenitas. Uji normalitas digunakan untuk menguji sebaran data yang diperoleh di masing-masing kelas berdistribusi normal atau tidak. Uji homogenitas dilakukan untuk mengetahui dari siswa datanya dari masing-masing kelas homogen atau tidak. Oleh karena data kemampuan awal siswa memenuhi uji prasyarat yaitu normal dan homogen, selanjutnya peneliti memberikan perlakuan kelas A diterapkan model pembelajaran kooperatif tipe TSTS dan kelas B diterapkan model pembelajaran kooperatif tipe TAI dan kelas $\mathrm{C}$ diterapkan model pembelajaran kooperatif tipe TPS. Uji dilanjutkan dengan uji Anova satu jalur.

\section{HASIL DAN PEMBAHASAN}

Penelitian telah dilakukan di SMK Muhammadiyah 1 Turi tahun pelajaran 2018/2019. Sebelum dilakukan perlakuan ke masing-masing kelas dilakukan tes hasil belajar matematika untuk memperoleh nilai kemampuan awal siswa. Dari hasil analisis data diperoleh hasil, untuk masing-masing kelas berdistribusi normal. Hal ini dapat 
ditunjukkan seperti pada tabel berikut :

Tabel 1. Tabel Distribusi Normal Kelas A,B dan C

\begin{tabular}{crrcc}
\hline Kelas & \multicolumn{1}{c}{$\chi^{\text {2hitung }}$} & \multicolumn{1}{c}{$\chi_{\text {2tabel }}$} & Derajat kebebasan & Keterangan \\
\hline A & 0,262 & 7,378 & 2 & Normal \\
B & 0,262 & 7,378 & 2 & Normal \\
C & 2,032 & 7,378 & 2 & Normal \\
\hline
\end{tabular}

Dari Tabel 1, terlihat bahwa dengan menggunakan uji beda rerata hasil belajar matematika antara ketiga kelas eksperimen dengan taraf siginifikan 0,05 tidak ada perbedaan secara signifikan.

Uji dilanjutkan dengan menguji homogenitas untuk data kemampuan awal siswa kelas A, kelas B dan kelas C. Dari hasil uji homogenitas diperoleh hasil pada Tabel 2.

Tabel 2. Rangkuman Uji Homogenitas Data Nilai kemampuan Awal Kelas A, Kelas B dan Kelas C

\begin{tabular}{cccc}
\hline \multicolumn{2}{c}{ Variansi } & Chi kuadrat hitung & Chi kuadrat tabel \\
\hline Variansi 1 & 291.747 & & \\
Vaeiansi 2 & 385,313 & 1,867 & 5,991 \\
Variansi 2 & 211,783 & & \\
\hline
\end{tabular}

Berdasarkan uji homogenitas dengan mengambil taraf signifikan 5\% derajat kebebasan dua diperoleh $\chi$ hitung $=1,867<\chi$ tabel $=5,991$ sehingga dapat disimpulkan bahwa kemampuan awal kelas A, kelas B dan kelas $\mathrm{C}$ homogen artinya kelompok varian berasal dari populasi yang homogen.

Pengujian dilanjutkan dengan menggunakan uji ANOVA satu jalur, hasil perhitungan uji beda rerata hasil belajar matematika dari ketiga kelas eksperimen dapat dijelaskan pada tabel berikut ini:

Tabel 3. Hasil Uji Beda Rerata Kemampuan Awal Siswa pada Kelas A, Kelas B dan Kelas C

\begin{tabular}{lccll}
\hline F hitung & F tabel & Taraf siginifikan & Dk & Kesimpulan \\
\hline 0,054 & 3,142 & $5 \%$ & 64 & Ho diterima H1 ditolak \\
\hline
\end{tabular}

Dari tabel 3 terlihat hasil uji perbedaan rerata hasil belajar matematika siswa sebelum diberi pembelajaran TPS, TAI dan TSTS menunjukan bahwa pada level signifikan 0,05, diperoleh Fhitung $=0,069<$ Ftabel $=3,142$, sehingga dapat disimpulkan tidak ada perbedaan yang bermakna rerata hasil belajar matematika pada kelas XI Akuntansi SMK Muhammadiyah 1 Turi Tahun Pelajaran 2018/2019 yang pembelajarannya menggunakan model pembelajaran TSTS,TAI maupun TPS. Tidak adanya perbedaan hasil belajar diantara ketiga kelas tersebut, dapat dipahami oleh karena guru menerapkan model pembelajaran yang sama pada ketiga kelas tersebut dan ketiga kelas tersebut bersifat homogen, artinya tidak ada ketiga kelas memiliki tingkat keefektifan yang sama.

Oleh karena kemampuan awal yang dimliki siswa kelas A, kelas B dan kelas C tidak ada perbedaan, sehingga peneliti melanjutkan memberikan perlakuan pada kelas A dengan menerapkan model pembelajaran kooperatif tipe TSTS, kelas B model pembelajaran TAI dan kelas C model pembelajaran TPS. Pembelajaran kooperatif 
diterapkan karena pembelajaran kooperatif amat membantu dalam mengembangkan hubungan antar personal di antara para siswa. Kesempatan siswa untuk menyampaikan gagasan dan menerima masukan dari dan antar mereka dapat meningkatkan percaya diri dan motivasi.

Setelah diberikan perlakuan selanjutnya dilakukan uji hipotesis, hasil perhitungan uji beda rerata hasil belajar matematika siswa pada ketiga kelas eksperimen dapat dijelaskan pada tabel berikut ini:

Tabel 4. Hasil Uji Beda Rerata Hasil Belajar Matematika Siswa pada Kelas A, Kelas B dan Kelas C

\begin{tabular}{lccll}
\hline F hitung & F tabel & Taraf siginifikan & Dk & Kesimpulan \\
\hline 0,069 & 3,142 & $5 \%$ & 64 & Ho diterima H1 ditolak \\
\hline
\end{tabular}

Dari Tabel 4 dapat dijelaskan bahwa Ho diterima dan H1 ditolak sehingga dapat disimpulkan bahwa tidak terdapat perbedaan yang signifikan nilai postest hasil belajar siswa antara kelas eksperimen dari ketiga kelas, yaitu kelas A, kelas B dan kelas C. Dari hasil tersebut dapat dipahami bahwa penggunaan model pembelajaran kooperatif tipe TSTS, tipe TAI dan tipe TPS sama-sama baik digunakan dalam menghasilkan kemampuan kognitif siswa pada materi lingkaran pada kelas XI SMK Muhammadiyah 1 Turi.

Hasil belajar antara ketiga kelas eksperimen tidak berbeda secara signifikan disebabkan adanya kesamaan karakteristik proses pembelajaran antara ketiga model pembelajaran yang diterapkan, yaitu sama-sama merupakan model pembelajaran kooperatif. Pada model pembelajaran kooperatif ini pelaksanaan pembelajarannya dilakukan secara berkelompok, meskipun ada sedikit perbedaan dalam pengelompokan di model TPS yakni dilakukan secara berpasangan. Pada model TSTS dan TPS pembelajaran diakhiri dengan presentasi perwakilan siswa di depan kelas sehingga siswa lebih berani mengungkapkan ide atau pendapatnya, tetapi pada model TAI diakhiri dengan guru menyajikan kembali materi yang telah disampaikan. Dari pelaksanaan ketiga model ini, sama-sama meningkatkan aktifitas belajar siswa, akan tetapi model TAI lebih menekankan pada keaktifan kerja sama dari siswa.

Oleh karena pada model TAI lebih ditekankan kerja sama dalam pelaksanaan pembelajaran siswa yang kurang pandai terbantu dengan siswa yang pandai, bisa saja terjadi kecenderungan ada sikap menggantungkan teman. Berbeda dengan model TPS, adanya kelompok yang berpasangan menjadikan siswa saling mengemukakan idenya dan sifat menggantungkan teman kurang begitu nampak. Untuk pelaksanaan model TSTS meskipun dalam pelaksanaan guru sulit untuk mengelola kelas, rasa percaya diri masing -masing siswa ada, sifat menggantungkan teman kurang begitu nampak. Pergerakan siswa di kelas lebih banyak dilakukan pada model TSTS dibanding model TAI dan TPS.

Kurang optimalnya pelaksanaan penggunaan model pembelajaran kooperatif tipe TPS yang ditemukan selama penelitian beberapa kelompok kurang aktif dalam berdiskusi dengan teman, sehingga dalam tahap pair (berbagi) kurang begitu lancar. Hal ini dapat dipahami oleh karena kalau siswa yang berkelompok sama-sama tidak memahami materi, maka masing-masing tidak dapat menyampaikan idenya/pendapatnya ke teman sekelompoknya. Pada pelaksanaan model pembelajaran TSTS kurang optimalnya pada waktu yang diperlukan untuk pembelajaran menjadi relatif lebih lama, karena adanya tahap siswa meninggalkan kelompok untuk bertamu dan siswa kembali ke kelompoknya masing-masing. Untuk pelaksanaan proses ini membutuhkan waktu yang lama, karena siswa tidak segera melaksanakannya. Pada pelaksanaan dengan TAI kurang dapat berjalan optimal karena ada beberapa siswa yang lebih menggantungkan ke teman satu kelompoknya. Padahal mereka paham dengan materinya, tetapi kekhawatiran salah dalam 
menyampaikan idenya.

\section{KESIMPULAN}

Hasil penelitian menunjukkan tidak ada perbedaan yang bermakna rerata hasil belajar matematika pada kelas XI Akuntansi SMK Muhammadiyah 1 Turi Tahun Pelajaran 2018/2019 yang pembelajarannya menggunakan model pembelajaran TSTS,TAI maupun TPS.

\section{DAFTAR PUSTAKA}

Achdiyat, Maman dan Andriyani, Fitriya. (2016). Hasil Belajar Matematika Ditinjau Dari Model Pembelajaran Teams Assisted Individualization (TAI). Jurnal: Formatif 6(3): hlm:246-255.

Agus Suprijono. (2012). Cooperatif Learning : Teori dan Aplikasi PAIKEM. Yogyakarta: Pustaka Pelajar.

Ali, A., \& Arif, W. P. (2019). Developing of guidance for laboratory practice of islamic science-integrated plant anatomy-physiology. Biosfer: Jurnal Pendidikan Biologi, 12(1), 70-82.

Ariyanto, Dimas Bagas; Sujadi,Imam; Setiawan,Rubono.2018.Penerapan Model Pembelajaran Kooperatif Tipe Two Stay - Two Stray (TSTS) Dalam Meningkatkan Kemampuan Pemecahan Masalah Matematika Materi Geometri Pada Siswa Kelas VIII -G SMP Negeri 1 Surakarta Tahun Pelajaran 2016/2017. Jurnal:Solusi 2(3) hlm 205-209

Darmawan, E., Alamsyah, M. R. N., Permadani, K. G., Pamungkas, S. J., Prajoko, S., Sukmawati, I., ... \& Zamzami, M. R. A. (2019). Integration of Simas eric with google classroom: enhancing biology students motivation and scientific writing. Biosfer: Jurnal Pendidikan Biologi, 12(1), 1-12.

Habibi, Ziyad dan Rusimamto, Puput Wanarti. (2014). Pengaruh Model Pembelajaran Kooperatif Tipe TSTS (Two Stay Two Stray) Terhadap Hasil Belajar Siswa Pada Mata Pelajaran Teknik Elektronika Dasar Di SMK Negeri 1 Jetis Mojokerto.Jurnal: Pendidikan Teknik Elektro 03(03)hlm 669 - 677

Herawati. (2015). Penerapan Model Pembelajaran Two Stay Two Stray Untuk Meningkatkan Prestasi Belajar Siswa Pada Materi Keliling Dan Luas Lingkaran Di Kelas VI SD Negeri 53 Banda Aceh. Jurnal: Peluang, Volume 3, Nomor $2 \mathrm{hlm}$ 95-105

Isfaeni, H., Corebima, A. D., Suwono, H., \& Rohman, F. (2018). The effectiveness of the printed books as a learning material in a one-day the molecular biology course. Biosfer: Jurnal Pendidikan Biologi, 11(2), 108-113.

Kesumawardani, Aryani Dwi; Marpaung, Rini Rita T; Yolida, Berti. (2016). Pengaruh Model Pembelajaran TPS Terhadap Aktivitas Belajar Siswa Dan Penguasaan Materi. Jurnal: Bioterdidik 4(1)

Krestian, Hery; Masriani;Hadi,Lukman. (2017). Pengaruh Pembelajaran Kooperatif Tipe Tai Terhadap Motivasi Dan Hasil Belajar Pada Materi Ikatan Kimia Jurnal : Jurnal Pendidikan dan Pembelajaran (JIPP) 6(1) hlm 1-13

Marlina, Hajidin, dan M. Ikhsan. (2014). Penggunaan Model Pembelajaran Kooperatif 
Tipe Think-Pair-Share (TPS) untuk Meningkatkan Kemampuan Komunikasi dan Disposisi Matematis Siswa di SMA Negeri 1 Bireuen. Jurnal: didaktik matematika 1(1) hlm 83-95

Meizha, Istiqomah dan Harini, Esti. 2014. Peningkatan Motivasi Dan Hasil Belajar Matematika Melalui Model Pembelajaran Kooperatif Tipe Team Assisted Individualisation. Jurnal : UNION 2(3) hlm 281-288

Nurmalaningrum dan Khotimah, Rita Pramujiyanti. 2018. Pembelajaran Matematika Dengan Model Pembelajaran Two Stay Two Stray Dan Think Pair Share Ditinjau Dari Kreativitas Belajar Siswa Kelas VII SMP Negeri 2 Karangdowo. Prosisiding KNPMP III.hlm:397-405.

Nurzakiaty, Ida. (2015). Penerapan Model Pembelajaran Kooperatif Tipe Team Assisted Individualization (TAI) Dalam Pembelajaran Integral Di Kelas Xii Ipa-2 Sma Negeri 8 Banda Aceh. Jurnal : Peluang,3(2) hlm 31-46

Ristanto, R. H., Zubaidah, S., Amin, M., \& Rohman, F. (2018a). The potential of cooperative integrated reading and composition in biology learning at higher education. International Journal of Educational Research Review, 3(1), 50-56.

Ristanto, R. H., Zubaidah, S., Amin, M., \& Rohman, F. (2018b). From a reader to a scientist: developing cirgi learning to empower scientific literacy and mastery of biology concept. Biosfer: Jurnal Pendidikan Biologi, 11(2), 90-100.

Rohmana, Qorry Aulya; Widodo, Nur; Kapti, Listijo. (2016). Penerapan Model Pembelajaran TSTS (Two Stay Two Stray) Dipadu Picture \& Picture Untuk Meningkatkan Keaktifan Dan Hasil Belajar Materi Jaringan Hewan Pada Siswa Kelas XI SMA. Jurnal Pendidikan: Teori, Penelitian, dan Pengembangan 1(10) hlm: 2071-2075.

Rohmawati, A. (2015). Efektivitas Pembelajaran. Jurnal Pendidikan Usia Dini. 9(1). 1532.

Sipayung,Natalia; Simanjuntak, Sinta Dameria. (2017). Efektivitas Pembelajaran Kooperatif Dengan Menggunakan Modul. Jurnal : Aksioma 6(3) hlm 393-398

Sumargiyani. (2015). Efektivitas Penggunaan Model Pembelajaran Number Head Together Terhadap Hasil Belajar Matematika Siswa SMP. Jurnal: AdMathEdu 5(2) hlm 193-202. 